\title{
Aggregation of hepatic melanomacrophage centers in S. herzbergii (Pisces, Ariidae) as indicators of environmental change and well-being
}

[Agregação de centros de melanomacrófagos hepáticos em S. herzbergii (Pisces, Ariidae)

como indicadores de mudança ambiental e de bem-estar]

H.C. Viana ${ }^{1}$, W.B. Jesus ${ }^{1 *}$, S.K.L. Silva ${ }^{2}$, M.B. Jorge $e^{3}$, D.M.S. Santos ${ }^{4}$, R.N.F. Carvalho Neta ${ }^{4}$

\author{
${ }^{1}$ Alunos de pós-graduação - Universidade Estadual do Maranhão (UEMA), Campus Paulo VI - São Luís, MA \\ ${ }^{2}$ Aluna de pós-graduação - Universidade Federal do Maranhão (UFMA) - São Luís, MA \\ ${ }^{3}$ Universidade Federal do Maranhão (UFMA) - São Luís, MA \\ ${ }^{4}$ Universidade Estadual do Maranhão (UEMA) - Campus Paulo VI - São Luís, MA
}

\begin{abstract}
The melanomacrophage centers (MMCs) in the liver of fish are indicators of environmental conditions, as they are involved in xenobiotic biotransformation. The objective of this study was to evaluate the number of MMC in the liver of juveniles and adults of Sciades herzbergii from areas with different levels of contamination. The fish were caught at three points (reference - A1, potentially impacted - A2 and contaminated - A3), in São José bay (Maranhão, Brazil), in four samples. The livers were subjected to the standard histological procedure and $5 \mu \mathrm{m}$ sections were stained with hematoxylin-eosin. In livers of A2 adult individuals $\left(260.50 \pm 161.50 \mathrm{MMCs} / \mathrm{mm}^{2}\right)$ they presented a greater number of MMCs when compared to $\mathrm{A} 3$ adults $\left(60.00 \pm 30.10 \mathrm{MMCs} / \mathrm{mm}^{2}\right)$. Juveniles showed considerable values in A1 (100.00 \pm 0.00 $\left.\mathrm{MMCs} / \mathrm{mm}^{2}\right)$ and A2 $\left(95.33 \pm 33.00 \mathrm{MMCs} / \mathrm{mm}^{2}\right)$ compared to juveniles in A3 $\left(49.00 \pm 0.00 \mathrm{MMCs} / \mathrm{mm}^{2}\right)$. These high values are unexpected for young people. The average number of MMC correlated with the rainy season in the region. The use of hepatic MMCs as a biomarker of exposure to pollutants, in particular substances from fisheries systems, such as ammonia and nitrite, proved to be adequate to differentiate areas with different levels of impacts.
\end{abstract}

Keywords: alterations, biomonitoring, biomarker, fish, liver

\section{RESUMO}

Os centros melanomacrófagos (MMCs) no fígado de peixes são indicadores das condições ambientais, pois estão envolvidos na biotransformação xenobiótica. O objetivo deste estudo foi avaliar o número de MMC no fígado de juvenis e adultos de Sciades herzbergii de áreas com diferentes níveis de contaminação. Os peixes foram capturados em três pontos (referência - A1; potencialmente impactado - A2; e contaminado - A3), na baía de São José (Maranhão, Brasil), em quatro amostras. Os fígados foram submetidos ao procedimento histológico padrão e cortes de 5 um foram corados com hematoxilina-eosina. Em figados de indivíduos adultos A2 (260,50 $\left.161,50 \mathrm{MMCs} / \mathrm{mm}^{2}\right)$, eles apresentaram maior número de MMCs quando comparados aos adultos A3 $\left(60,00 \pm 30,10 \mathrm{MMCs} / \mathrm{mm}^{2}\right)$. Os juvenis apresentaram valores elevados em A1 $\left(100,00 \pm 0,00 \mathrm{MMCs} / \mathrm{mm}^{2}\right)$ e A2 $\left(95,33 \pm 33,00 \mathrm{MMCs} / \mathrm{mm}^{2}\right)$ quando comparados aos juvenis em A3 $\left(49,00 \pm 0,00 \mathrm{MMCs} / \mathrm{mm}^{2}\right)$. Esses altos valores são inesperados para os jovens. O número médio de MMC correlacionou-se com a época chuvosa na região. A utilização de MMCs hepáticos como biomarcador de exposição a poluentes, em particular substâncias provenientes de sistemas pesqueiros, como amônia e nitrito, mostrou-se adequada para diferenciar áreas com diferentes níveis de impactos.

Palavras-chave: alterações, biomonitoramento, biomarcador, peixe, fígado

Recebido em 18 de fevereiro de 2021

Aceito em 6 de abril de 2021

*Autor para correspondência (corresponding author)

E-mail: wandadossantosbatista@gmail.com 


\section{INTRODUCTION}

Melanomacrophage centers (MMCs) consist of macrophages, such as phagocytic cells and fragments, mainly erythrocytes and pigments, such as melanin, hemosiderin and lipofuscin, located in the reticuloendothelial liver tissue, kidney and pancreas (Agius and Roberts, 2003). MMCs are found in several vertebrates such as reptiles (Johnson et al., 1999; Domiciano et al., 2017) amphibians (Franco-Belussi et al., 2013, Franco-Belussi and de Oliveira, 2016, Wu et al., 2017) and fish (Mela et al., 2013; Sales et al., 2017). The number of melanomacrophage centers, their size and distribution vary according to species, organ, age, nutritional level and stress conditions (Fishelson, 2006). The function of the MMCs is to destroy, detoxify or recycle foreign materials (Van der Oost et al., 2003).

Fish liver is considered a good indicator of environmental stress conditions, as it is responsible for several vital functions in the physiology of these animals, both in anabolism and catabolism, and in xenobiotic metabolism (Passantino et al., 2014). In this context, liver histopathology can be used as an appropriate methodology for the detection of fish exposure to various pollutants (heavy metals, polychlorinated biphenyls - PCBs, polycyclic aromatic hydrocarbons - PAHs) from environmental anthropic activities (Faccioli et al., 2014). Sciades herzbergii is a species of catfish distributed on the South American continent, the Caribbean, Atlantic rivers and estuaries from Colombia to Brazil (Marceniuk, 2005). Adults of this species occur in estuaries with turbid waters, mangroves, low river courses, tolerate salinity changes and are found in shallow coastal regions (Silva et al., 2016). Its fishing is carried out mainly by smallscale and subsistence fishing communities. Due to the low cost in markets and fairs, its fishing is intense and occurs all year round at the mouths of the São Luis River, being one of the main fish traded in the capital of Maranhão.

Next to these areas is the low course of the Santo Antônio River, where a massive fishery network is settling up and launching effluents without any previous treatment, in areas where heavy fishing takes place. Concern increases in the rainy period when fishery water is constantly drained, preventing collapse or exceeding the acceptable water level. There are some studies with this species in aquatic contamination biomonitoring programs in nearby and similar regions (Carvalho-Neta et al., 2012; Sousa et al., 2013a, 2013b; Carvalho-Neta et al., 2014). However, the approach based on MMCs in S. herzbergii liver to evaluate anthropic impact is unknown in the state of Maranhão. This work aimed to validate hepatic MMCs in $S$. herzbergii as biomarkers environmental pollutant exposure, in particular fishery effluents in São José Bay (Maranhão, Brazil).

\section{MATERIALS AND METHODS}

The capture of fish was authorized by the Ethics Committee of Maranhão State University (number 064/2017-2018 CRMV-MA) and met the guidelines of the Brazilian College for Animal Experimentation (Proteção..., 2018). Four collections were carried out between the periods of September and December 2017 and March and May 2018. For locomotion to the collection points, a motorized vessel (biana) was used, conducted by artisanal fishermen. Sampling of $S$. herzbergii specimens took place at three points distributed in São José bay, in Golfão Maranhense. The first point (A1 - ${ }^{\circ} 27^{\prime} 47.58$ "S $44^{\circ} 2$ '45.42" W) was farther from the coast, considered in this study as a low-polluted area, as there is no discharge of domestic effluents in bodies of water. A second area was considered the potentially impacted point (A2 - $2^{\circ} 29^{\prime} 36.54$ "S $44^{\circ} 3{ }^{\prime} 34.38^{\prime \prime}$ W), located in the Santo Antônio river channel, close to the stream that receives the fishing effluents. The third point (A3 - $2^{\circ} 33^{\prime} 18$, 36 "S $44^{\circ} 3^{\prime} 10,02$ " W) was considered potentially impacted, due to the nearby human actions, such as discharge of domestic effluents without any treatment (Figure 1).

For basic histological analysis and MMC identification, the fish were dissected, and liver samples were set $10 \%$ formaldehyde, subsequently dehydrated in increasing alcohol concentrations and embedded in paraffin. Liver sections of liver $(5 \mu \mathrm{m})$ were stained with hematoxylin-eosin (H\&E) (Merck) for liver structure description and slide reading was done with the aid of light microscopy (ZEISS). Evisceration was performed for macroscopic identification of maturational stages, where: I Immature, II - In development, III - Able to spawn, IV - Regression and V - Regeneration (Brown-Peterson et al., 2011). A quantitative 
analysis of MMC aggregation was performed on hepatic tissue sections of the fish. Each digital field was photographed using Zen Imaging Axiovision 4.8 software mounted on the optical microscope with the $4 \mathrm{X}, 10 \mathrm{X}$ and $40 \mathrm{X}$ lenses. MMC aggregation was identified through image analysis in the ImageJ software and randomly quantified the number of MMCs per $\mathrm{mm}^{2}$. Each section was removed from the liver's central region and it was possible to measure the whole organ.

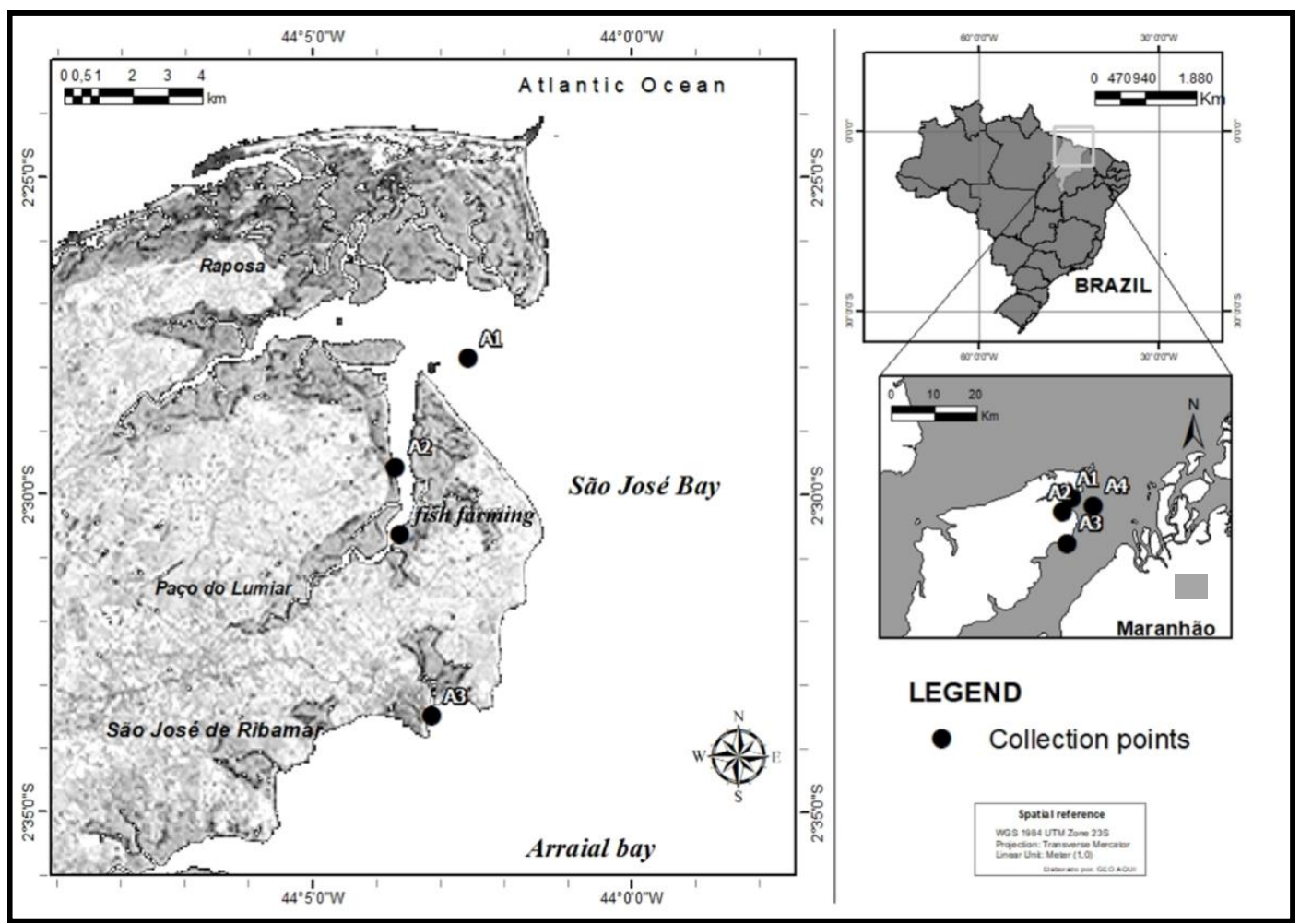

Figure 1. Geographic location of sampling points. A1 - reference, A2 - impacted and A3 - contaminated.

Histological appearance of the normal liver of $S$. herzbergii is shown in Figure 2E, Figure 2F. Hepatic parenchyma is composed of the central lobular vein (CLV) surrounded by hepatocyte cords and sinusoid capillaries. The hepatocyte presented a polygonal shape with a spherical and centralized nucleus (Passantino et al., 2014). The hepatic parenchyma was homogenous with hepatocytes of polygonal forms containing a spherical nucleus; hepatic cytoplasm showed to be weakly basophilic and with presence of lipid cells in small and large vacuoles (Figure 2A). Hepatocytes were organized as branched and anastomosed cords arrayed by sinusoid networks. The melanomacrophage centers in the hepatic parenchyma, which are composed of cell and pigment aggregation, contain iron ions, lipofuscin and ceroids (Figure 2B).
Adipose metaplasia and tumor presence was also observed, as there was no sign of mitosis or necrosis, it was not possible to indicate benignity, this psamomatous body was found in hepatopancreas tissue (Figure 2C). The hepatopancreas are the main digestive enzyme supply sites, which in carnivorous fish, have higher lipase activity when compared to omnivorous and herbivorous species. On the other hand, bile, secreted by hepatocytes, can enter the proximal part of the intestine or be stored in the gallbladder, with the function of facilitating digestion and absorption of lipids and lipophilic substances, such as fat-soluble vitamins (A, D, E and K) (Arantes et al., 2016). Hepatocytes were thus observed in the bile duct epithelium, both in juvenile and adult individuals (Figure 2D). 

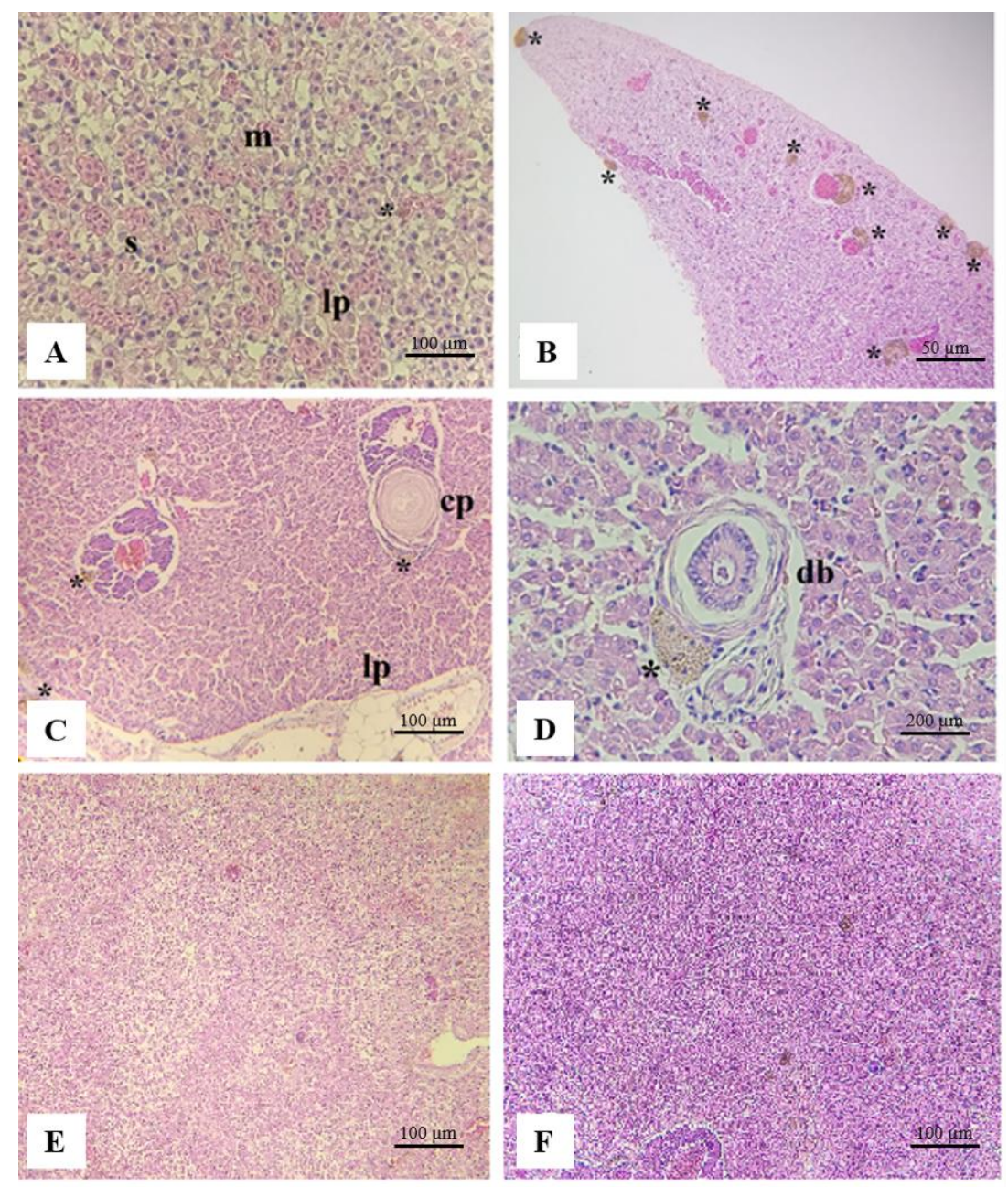

Figure 2. Photomicrograph of the liver of S. herzbergii sampled at three different points of the São José bay - MA. (A) H\&E staining of a section of the liver showing lipid components. (B) Melanomacrophage center presence. (C) Lipid cells, psamomatous body in hepatopancreas tissue and MMCs. (D) antibodies surrounding the hepatocyte cytoplasm as well as the bile duct epithelium. (E, F) The histological appearance of normal liver. Asterisk: melanomacrophage center; m: macrophages; lp: lipid cells; s: sinusoids; pb: psamomatous body; bd: bile duct.

Condition factor $(\mathrm{K})$ is a quantitative indicator of the individual's degree of healthiness or wellbeing. It is used to indicate variations in population density and food conditions. The value reflects recent nutritional conditions and/or reserve expenditures on metabolic activities, allowing relationships with environmental conditions and species' behavioral aspects (Le Cren, 1951; Vazzoler, 1996). K was estimated for each individual and their average obtained for each period, according to the expression: $\mathrm{K}=$ $\mathrm{Wt} / \mathrm{Ltb} \times 100$, where: $\mathrm{Wt}=$ total weight, $\mathrm{Lt}=$ total length and $b=$ weight/length angular coefficient. The average number of $\mathrm{MMC} / \mathrm{mm}^{2}$ was compared between sites using the Kruskal-Wallis test. For variables with a significant test result, comparisons between pairs among different sites were made using the non-parametric MannWhitney U test, controlling Type I error between tests by Bonferroni adjustment. Statistical differences were considered significant when $\mathrm{P}<0.05$. Data was checked for normality using the Kolmogorov-Smirnov or Shapiro-Wilk tests. Statistical analyses were performed using the software PAlaeontological STatistics (PAST), version 1.0.0.0 (Ryan et al., 2001) and statistical significance was accepted for $p \leq 0.05$. Results were expressed by average and standard error. An ANOVA and Tukey test were performed for different sampled sites and condition factor. 


\section{RESULTS}

A total of 73 individuals (12 juveniles and 10 adults-A1, 16 juveniles and 4 adults -A2 and 7 juveniles and 24 adults in A3) were collected. Juveniles and adults in the A1 area showed a similar percentage in relation to the number of specimens, with a slight numerical advantage compared to the juvenile. In relation to area A2, the difference reached $80 \%$ in relation to juveniles and $20 \%$ of adults. In the A3 area, the adult presence $(77 \%)$ predominated in relation to juvenile (23\%) Adult fish at point A1 were the largest on average total length, both juveniles $(28.01 \pm 3.05 \mathrm{~cm})$ and adults $(36.95 \pm 2.43 \mathrm{~cm})$.
The adults at point A2 had an average length of $(31.28 \pm 2.72 \mathrm{~cm})$ and juvenile presented the lowest total length averages $(26.01 \pm 8.92 \mathrm{~cm})$ of the entire collection. At point A3, average adult length was $(29.94 \pm 4.02 \mathrm{~cm})$ and juvenile $(26.76$ $\pm 2.27 \mathrm{~cm})$. The maturation stage of the fish caught in this study showed the following data: in A1 there was a rate of 41 juveniles, A2 there was a frequency of 45 juveniles in stage I and 35 in stage II and A3 presented 35 adults in stage III and 32 in stage IV. The number of melanomacrophage centers $\left(\mathrm{MMCs} / \mathrm{mm}^{2}\right.$ ) in juvenile and adult $S$. herzbergii livers at three capture sites (Figure 3). The MMC number was significantly low in livers of area youth A3 $(P<0.05)$ compared to youth from areas $\mathrm{A} 2$ and $\mathrm{A} 1$.

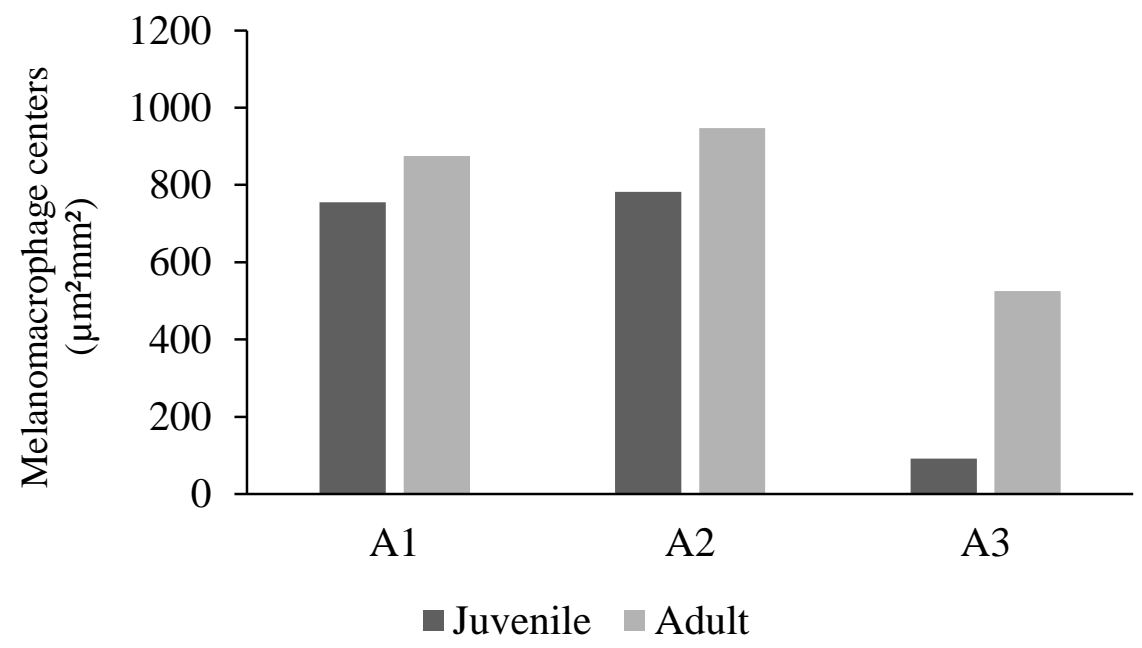

Figure 3. Number of melanomacrophage centers $\left(\mathrm{MMCs} / \mathrm{mm}^{2}\right)$ (standard error) in juvenile and adult $S$. herzbergii livers at the three capture sites. Asterisk (*) indicates a significant statistic difference comparing the reference and impacted areas.

The $S$. herzbergii condition factor ranged from 1.0387 to 0.9672 for area A1. K ranged from 1.0432 to 0.9700 in area $\mathrm{A} 2$ and decreased from 1.0433 to 0.9800 in area A3. The ANOVA did not show significant values for the different sampling points and the fish condition factor. The condition factor of each fish was examined, and the monthly average indicated that in at least two different times of the year, fish were in good condition. The melanomacrophage center aggregation was lower in adults from area A3 (30.50 \pm 12.60 $\mathrm{MMCs} / \mathrm{mm}^{2}$ ) in May 2018 and higher in area A2 adults $\left(260.50 \pm 161.50 \mathrm{MMCs} / \mathrm{mm}^{2}\right)$ in March 2018. In juveniles, a greater quantification of melanomacrophage centers was observed in areas A1 $(100.00 \pm 0.00)$ and A2 $(95.33 \pm 33.00)$, in
March and May 2018, respectively. Observations of the average number of MMC aggregates showed a difference in the periods sampled for areas A1 and A2, showing correlation with the period of rains (in accordance with the INMET, 2018).

\section{DISCUSSION}

The large amount of aggregation of melanomacrophage centers (MMCs) in juvenile and adult individuals from areas with a history of contamination indicates that MMCs in $S$. herzbergii can be used as an indicator of environmental change and animal welfare. Histological analysis of the liver of $S$. herzbergii 
allowed the identification of both free and grouped melanomacrophages, mainly near blood vessels. The data found in this study confirms and amplifies available information about fish MMCs of fish that are considered catabolism residues of several compounds (Ribeiro et al., 2011). Lipofuscin and ceroid are consecutive products of the same oxidation process, derived from a cell membrane rupture or lipid metabolism rupture, and increase with age.

These pigments can accumulate in fish exhibiting a wide variety of pathological conditions, including nutritional deficiencies, bacterial and viral diseases, and disorders caused by toxic material (Agius, 1979). Stress itself can increase macrophage-like cells and increase red cell degradation (Peters and Schwarzer, 1985). Therefore, in the presence of environmental pollution, which may be responsible for increased cell damage, increased phagocytic activity could be expected, with consequent increase in MMCs. Hepatic S. herzbergii melanomacrophages are involved in the activity of storing, relocating, and recycling iron compounds from sterile or damaged venous red blood cells. In this study, the highest number of MMCs was detected in organisms from area A2 (1833) and correspond to the youngest individuals in the study.

This fish group also exhibited the highest average $\mathrm{MMCs} / \mathrm{mm}^{2}$ compared to other areas. It presented a similar number (1630) to area A3 and three times more than area A1 (617). These results are in conflict with literature data because a strong correlation between fish aging - hence tissue degeneration - and increase in the number and size of MMCs have been demonstrated in different species' liver and kidney (Agius, 1980). In this case, it is likely that the environment in question is undergoing a contamination process and mainly juveniles. In addition to these physiological changes related to aging, an increase in the MMC number was also demonstrated in liver, spleen and kidney of fish stressed due to a polluted environment (Agius and Roberts, 2003). As a result, the role of these aggregates as biomarkers for the effects due to environmental exposure to polluting chemical substances has been extensively documented in freshwater and marine teleosts (Passantino et al., 2005; Mela et al., 2007; Pascoli et al., 2011; Van Dyk et al., 2012; Passantino et al., 2014; Zhang et al., 2014; Arantes et al., 2016; Basilone et al., 2018) and in the case of the fish from the environments evaluated in this study.

There is little research on the environmental situation of the Santo Antônio River basin, where its low course is the target of our investigation. It is known that there is irregular occupational movement, followed by accelerated urban occupation in mangroves and gallery forest areas, favoring the destruction of flora and fauna, and consequently diminishing the region's water system quality. The upper and middle course is totally impacted by disorderly occupation and leaching processes added to the release of in natura sewage. The presence of heavy metals (iron, mercury, aluminum, lead and cadmium), not complying Brazilian legislation (resolution 357/2005) (Brasil, 2005), has already been observed in the area investigated in recent studies (Cantanhêde et al., 2016). In addition, microbial bivalve contamination was associated with high levels of microbiological contamination, especially in the period of the most intense rains and high risk for human consumption (Ribeiro $e t$ al., 2016).

The low course is considered preserved; however, it is possible to observe similar occupational characteristics in the middle and upper reaches of the river. Growing fishery activity and also the scarcity of documented material on contamination by organic material coming from fishery systems in the region studied, makes this work an unprecedented investigation in this context. In similar regions, where there is already an intense and well-documented fishery system, it is possible to affirm that effluents from these systems, when released without previous treatment, increase phosphorus and nitrogen levels present in fish feed. There is also a greater introduction of organic matter in the periods of expenditure, which causes a decrease of dissolved oxygen in the water, essential for aquatic life maintenance (Simões et al., 2007).

The variation in the number of melanomacrophage centers to monitor fish healthiness conditions has been shown to be a good indicator of environmental changes (Balamurugan et al., 2012). MMC aggregation was high in March and May of 2018 (rainy period). It is likely due to environmental changes in that particular area. These results show the effectiveness of MMC use as an indicator of fish 
exposure to environmental pollution and confirm, through the high number of MMCs found in juveniles $S$. herzbergii, that areas close to fisheries are suffering from exposure to organic compounds of anthropic origin higher than the other groups of fish studied. Observations showed that the liver of juveniles $S$. herzbergii possessed unexpectedly large amount of melanomagnetic centers compared to adult fish, being a potential indicator of environmental changes indicative of fishery system impacts in the northeastern Amazon area. Through these observations, indepth studies on juveniles and adults of $S$. herzbergii are suggested to obtain useful information for the evaluation of fish welfare and/or risk to human health.

\section{CONCLUSIONS}

In conclusion, this study confirms the importance of the use of hepatic MMCs as exposure biomarkers to environmental pollutants, in particular fishery system effluents. MMCs in $S$. herzbergii showed differences in the individuals from analyzed environments, being able to differentiate areas with different environmental impact levels.

\section{ACKNOWLEDGEMENTS}

I would like to thank to FAPEMA (Fundação de Amparo à Pesquisa e ao Desenvolvimento Científico e Tecnológico do Estado do Maranhão) and the research by LABOAq (Laboratório de Biomarcadores em Organismos Aquáticos) and GPEMAAq (Grupo de Pesquisa em Ecotoxicologia e Monitoramento de Ambientes Aquáticos). Funding: This work was supported by Maranhão State Research Foundation - FAPEMA (Fundação de Amparo à Pesquisa e ao Desenvolvimento Científico e Tecnológico do Estado do Maranhão) (Grant number: BM02175/17).

\section{REFERENCES}

AGIUS, C. Phylogenetic development of melanomacrophage centres in fish. J. Zool., v.191, p.1131, 1980.

AGIUS, C. The role of melano- macrophage centres in iron storage in normal and diseased fish. J. Fish Dis., v.2, p.337-343, 1979.
AGIUS, C.; ROBERTS, R.J. Melano-macrophage centres and their role in fish pathology. J. Fish Dis., v.26, p.499-509, 2003.

ARANTES, F.P.; SAVASSI, L.A.; SANTOS, H.B.; GOMES, M.V.T. et al. Bioaccumulation of mercury, cadmium, zinc, chromium, and lead in muscle, liver, and spleen tissues of a large commercially valuable catfish species from Brazil. An. Acad. Bras. Cienc., v.88, p.137-147, 2016.

BALAMURUGAN， S.; BALARAMAN， D.; KUMARAN, S. et al. Melanomacrophage centers aggregation in $P$. lineatus spleen as bio-indicator of environmental change. Asian Pacific J. Trop. Dis., v.2, Suppl.2, p.S635-S638, 2012.

BASILONE, G.; GARGANO, A.; CORRIERO, A. et al. Liver melanomacrophage centres and CYP1A expression as response biomarkers to environmental pollution in European anchovy (Engraulis encrasicolus) from the western Mediterranean Sea. Mar. Pollut. Bull., v.131, Part. A, p.197-204, 2018.

BRASIL. Ministério do Meio Ambiente Conselho Nacional do Meio Ambiente. Resolução $\mathrm{n}^{\circ} 357$, de 17 de março de 2005. Diário Oficial da União, Brasília. Available in: http://www.mma.gov.br/port/conama/legiabre.cf m?codlegi=459. Accessed in: 5 Aug. 2018).

BROWN-PETERSON, N.J.; WYANSKI, D.M.; SABORIDO-REY, F.; MACEWICZ, B.J. et al. A Standardized terminology for describing reproductive development in fishes. Mar. Coast. Fish., v.3, p.52-70, 2011.

CANTANHÊDE, S.M., SILVA CASTRO, G., PEREIRA, N.J., PINHO CAMPOS, J.S., et al. Evaluation of environmental quality of two estuaries in Ilha do Maranhão, Brazil, using histological and genotoxic biomarkers in Centropomus undecimalis (Pisces, Centropomidae). Environ. Sci. Pollut. Res., v.23, p.21058-21069, 2016.

CARVALHO NETA, R.N.F.; SOUSA, D.B.P.; ALMEIDA, Z.S.; SANTOS, D.M.S. et al. A histopathological and biometric comparison between catfish (Pisces, Ariidae) from a harbor and a protected area, Brazil. Aquat. Biosyst., v.10, p.12, 2014. 
CARVALHO-NETA, R.N.F.; TORRES, A.R.; ABREU-SILVA, A.L. Biomarkers in catfish Sciades herzbergii (teleostei: ariidae) from polluted and non-polluted areas (São Marcos' Bay, Northeastern Brazil). Appl. Biochem. Biotechnol., v.166, p.1314-1327, 2012.

DOMICIANO, I.G.; DOMIT, C.; BRACARENSE, A.P.F.R.L. The green turtle Chelonia mydas as a marine and coastal environmental sentinels: Anthropogenic activities and diseases. Semin. Cienc. Agrar., v.38, p.34173434, 2017.

FACCIOLI, C.K.; CHEDID, R.A.; BOMBONATO, M.T.S.; VICENTINI, C.A. et al. Morphology and Histochemistry of the Liver of Carnivorous Fish Hemisorubim platyrhynchos. Int. J. Morphol., v.32, p.715-720, 2014.

FISHELSON, L. Cytomorphological alterations of the thymus, spleen, head-kidney, and liver in cardinal fish (Apogonidae, Teleostei) as bioindicators of stress. J. Morphol., v.267, p.5769, 2006.

FRANCO-BELUSSI, L.; CASTRUCCI, A.M.L.; OLIVEIRA, C. 2013. Responses of melanocytes and melanomacrophages of Eupemphix nattereri (Anura: Leiuperidae) to Nle4, D-Phe7- $\alpha$ melanocyte stimulating hormone and lipopolysaccharides. Zoology, v.116, p.316-324, 2013.

FRANCO-BELUSSI, L.; OLIVEIRA, C. 2016. The spleen of Physalaemus nattereri (Amphibia: Anura): morphology, melanomacrophage pigment compounds and responses to $\alpha$ melanocyte stimulating hormone. Ital. J. Zool., v.83, p.298-305, 2016.

INMET - Instituto Nacional de Meteorologia. Histórico de dados meteorológicos. Ano 2018. Available in: https://portal.inmet.gov.br/. Accessed in: 17 May 2018).

JOHNSON, J.C.; SCHWIESOW, T.; EKWALL, A.K.; CHRISTIANSEN, J.L. Reptilian melanomacrophages function under conditions of hypothermia: Observations on phagocytic behavior. Pigment Cell Res., v.12, p.376-382, 1999.

LE CREN, E.D. The length-weight relationship and seasonal cycle in gonad weight and condition in the perch (Perca fluviatilis). J. Anim. Ecol., v.20, p.201-219, 1951.
MARCENIUK, A.P., 2005. Chave para identificação das espécies de bagres marinhos (Siluriformes, Ariidae) da costa brasileira. Bol. Inst. Pesca, v.31, p.89-101, 2005.

MELA, M.; GUILOSKI, I.C.; DORIA, H.B.; RANDI, M.A.F. et al. Effects of the herbicide atrazine in neotropical catfish (Rhamdia quelen). Ecotoxicol. Environ. Saf., v.93, p.13-21, 2013.

MELA, M.; RANDI, M.A.F.; VENTURA, D.F.; CARVALHO, C.E.V. et al. Effects of dietary methylmercury on liver and kidney histology in the neotropical fish Hoplias malabaricus. Ecotoxicol. Environ. Saf., v.68, p.425-435, 2007.

PASCOLI, F.; NEGRATO, E.; DI GIANCAMILlO, A.; BERTOTTO, D. et al. Evaluation of oxidative stress biomarkers in Zosterisessor ophiocephalus from the Venice Lagoon, Italy. Aquat. Toxicol., v.101, p.512-520, 2011.

PASSANTINO, L.; CIANCIOTTA, A.; JIRILLO, F.; CARRASSI, M. et al. Lymphoreticular system in fish: Erythrocytemediated immunomodulation of macrophages contributes to the formation of melanomacrophage centers. Immunopharmacol. Immunotoxicol., v.27, p.147-161, 2005.

PASSANTINO, L.; SANTAMARIA, N.; ZUPA, R.; POUSIS, C. et al. 2014. Liver melanomacrophage centres as indicators of Atlantic bluefin tuna, Thunnus thynnus L. wellbeing. J. Fish Dis., v.37, p.241-250, 2014.

PETERS, G.; SCHWARZER, R. Changes in hemopoietic tissue of rainbow trout under influence of stress. Dis. Aquat. Organ., v.1, p.1$10,1985$.

PROTEÇÃO e bem estar de animais de laboratório. COBEA, 2018. Available in: http://www.cobea.org.br/. Accessed in: 17 May 2018).

RIBEIRO, E.B.; BASTOS, L.S.; GALENO, L.S.; MENDES, R.S. et al. Integrated assessment of biomarker responses and microbiological analysis of oysters from São Luís Island, Brazil. Mar. Pollut. Bull., v.113, p.182-186, 2016. 
RIBEIRO, H.J.; PROCÓPIO, M.S.; GOMES, J.M.M.; VIEIRA, F.O. et al. Functional dissimilarity of melanomacrophage centres in the liver and spleen from females of the teleost fish Prochilodus argenteus. Cell Tissue Res., v.346, p.417-425, 2011.

RYAN, P.D.; HAMMER, O.; HARPER, D.A. Past: paleontological statistics software package for education and data analysis. Palaeontol. Electron., v.4, 9p., 2001.

SALES, C.F.; SILVA, R.F.; AMARAL, M.G.C.; DOMINGOS, F.F.T. et al. 2017. Comparative histology in the liver and spleen of three species of freshwater teleost. Neotrop. Ichthyol., v.15, e160041, 2017.

SILVA, W.C.; MARCENIUK, A.P.; SALES, J.B.L.; ARARIPE, J. Early Pleistocene lineages of Bagre bagre (Linnaeus, 1766) (Siluriformes: Ariidae), from the Atlantic coast of South America, with insights into the demography and biogeography of the species. Neotrop. Ichthyol., v.14, e150184, 2016.

SILVA, W.C.; MARCENIUK, A.P.; SALES, J.B.L.; ARARIPE, J. Early Pleistocene lineages of Bagre bagre (Linnaeus, 1766) (Siluriformes: Ariidae), from the Atlantic coast of South America, with insights into the demography and biogeography of the species. Neotrop. Ichthyol., v.14, e150184, 2016.

SIMÕES, F.D.S.; YABE, M.J.D.S.; MOREIRA, A.B.; BISINOTI, M.C. Avaliação do efeito da piscicultura em sistemas aquáticos em assis e Cândido Mota, São Paulo, por indicador de qualidade da água e análise estatítica multivariada. Quim. Nova, v.30, p.1834-1841, 2007.
SOUSA, D.B.P.; ALMEIDA, Z.S.; CARVALHO-NETA， R.N.F. Biomarcadores histológicos em duas espécies de bagres estuarinos da Costa Maranhense, Brasil. Arq. Bras. Med. Vet. Zootec., v.65, p.369-376, 2013 a.

SOUSA, D.B.P.; ALMEIDA, Z.S.; CARVALHO-NETA, R.N.F. Integrated analysis of two biomarkers in Sciades herzbergii (Ariidae , Siluriformes ), to assess the environmental impact at São Marcos ' Bay, Maranhao, Brazil. Lat. Am. J. Aquat. Res., v.41, p.305-312, 2013 b.

VAN DER OOST, R.; BEYER, J.; VERMEULEN, N.P.E. Fish bioaccumulation and biomarkers in environmental risk assessment: a review. Environ. Toxicol. Pharmacol., v.13, p.57149, 2003.

VAN DYK, J.C.; COCHRANE, M.J.; WAGENAAR, G.M. Liver histopathology of the sharptooth catfish Clarias gariepinus as a biomarker of aquatic pollution. Chemosphere, v.87, p.301-311, 2012.

VAZZOLER, A.E.M. Biologia e reprodução de peixes teleósteos: teoria e prática. Maringá: Eduem Press, 1996. 169p.

WU, C.; ZHANG, Y.; CHAI, L.; WANG, H. Histological changes, lipid metabolism and oxidative stress in the liver of Bufo gargarizans exposed to cadmium concentrations. Chemosphere, v.179, p.337-346, 2017.

ZHANG, H.; PAN, L.; TAO, Y. Toxicity assessment of environmental pollutant phenanthrene in clam Venerupis philippinarum using oxidative stress biomarkers. Environ. Toxicol. Pharmacol., v.37, p.697-704, 2014. 